\title{
OFFICER EDUCATION POLICY DEVELOPMENT IN THE CONTEXT OF THE CHANGING EUROPEAN SECURITY AND DEFENCE IDENTITY
}

\author{
Capt (OF-2) Aleksandras Melnikovas \\ General Jonas Žemaitis Military Academy of Lithuania
}

\begin{abstract}
The article analyzes the genesis of officer education policy in Europe and delineates the major patterns of its development. On the basis of literature analysis, officer education concept is defined and four main officer education models in Europe are distinguished. The article presents an overview of the European Security and Defence Identity (ESDI) evolution after the World War II (WWII), including three periods of its formation, and identifies the development of the Common Security and Defence Policy (CSDP) of the European Union (EU). The emergence of the most recent officer education model is examined within the context of the CSDP development and the Europeanization of officer education.

The article provides a contextual analysis of four distinct officer education models. Further analysis of officer education paradigms reveals the cyclic nature of officer education policy, thus identifying five main elements fostering officer education policy development. At the end of the article, officer education policy development model is presented.
\end{abstract}

Keywords: officer education policy, Europeanization of officer education, European Security and Defence Identity.

\section{Introduction}

The destabilization of the security environment, technological development and conceptual changes in military conflicts contribute to the continuous development of military personnel training and education policy, which is one of the basic means to ensure the functionality of the military in the changing environment.

Recent challenges in the security environment have encouraged the EU and NATO member states to constantly review their defence and security policies. The deteriorating security context and political change, i.e. the Brexit referendum, the United States (US) presidential election and the change of the US foreign policy foster the uncertainty of the security situation in Europe (Black et al., 2017). The EU leaders are increasingly focusing on the CSDP and the ESDI within NATO. In response to political developments, in 2016, the EU initiated the steps to consolidate the CSDP, which delineated a qualitatively new 'level of ambition' for the 
implementation of possible civilian missions and military operations (Blockmans, 2016).

The changing security environment in the EU and NATO poses new challenges to the armed forces, which is why it is extremely important to prepare and react in a timely manner in order to meet the operational, tactical and strategic requirements. Timely developments in military personnel education policies can make a significant contribution to ensuring the operational readiness of the military and preparing for an adequate and effective response to qualitatively new conventional and non-conventional threats.

Foot (2001) argues that the change in the paradigm of officer education is often driven by negative military experience that reveals the inability of the military to perform its tasks in a changed strategic, tactical or operational environment, which altogether leads to reactive officer education policy formation. Based on historical background, it can be argued that the genesis of officer education and training policy is often promoted by the reflective analysis of negative military experience, which reveals the inability of the military to perform its tasks in a changing strategic, tactical or operational environment. Officer education policies tend to be reactive in nature. The fundamental changes often take place post factum, which highlights the straggling nature of officer education policy development as the armed forces are at best prepared to respond to the threats that were relevant in the past and are often not prepared to respond effectively to the threats that will be relevant in the future.

Timely changes of military personnel education policy can ensure the operational readiness of the armed forces and contribute to the preparation for an adequate and effective response to qualitatively new conventional and nonconventional threats. In order to form a proactive officer education policy, it is crucial to define the main elements of officer education policy development; therefore, a problem question can be formulated as follows: what fosters the development of officer education policy in Europe?

The object of the research is the officer education policy.

The aim of the research is to explore the genesis of officer education policy in Europe and to define the patterns of its development.

\section{In order to achieve the aim, the following tasks were set:}

1. To define the concept of officer education;

2. To analyze the interchange of officer education models in Europe and to explore the context of the Europeanization of officer education;

3. To identify the main elements of officer education policy formation in Europe and to construct a theoretical model of the policy development.

Research methods: literature and document analysis. 


\section{The Definition of Officer Education}

Military training and education is an essential tool for sustaining high operational readiness and professionalism of the armed forces, which directly contributes to ensuring national and international security. According to Foot (2001), professionalization of officer training in Europe and purposeful education of officers as the basis for functional armed forces was introduced in the 19th century. The concept of military education is a subject for constant change and different interpretations, thus it is crucial to provide a clear definition of officer education.

Historically, professional military education is a basic term used to define the preparation of officers for the implementation of day-to-day duties. Professional military education is usually associated with the development of vocational skills and expertise, which ensure the professionalism of officers in 'management of violence' (Huntington, 1981). This notion of an officer as a professional on the battlefield was developed after the WWII in order to fulfill the requirements for armed forces to deal with conventional threats. Downes (1985) argues, though, that the 'management of violence' does not fully cover the area of professional military expertise as the military may be assigned both war-time as well as peacetime tasks, thus professional military education aims to provide the skills and knowledge necessary for the performance of professional tasks. Libel (2016) also notices reasonably that an army officer is a member of state bureaucracy, thus expert military knowledge includes both formal knowledge and professional skills.

Education of professional officers has always been a priority for the military, although the interpretation and use of the term education have undergone certain changes. The textbook Leadership and Education (2008) defines the term education as 'learning with the aim of earning qualification within a given area' (Leadership and Education, 2008 p. 492) and relates the goal of military education to the implementation of political objectives aimed at achieving a certain composition of defence system. Libel (2016) notices that historically professional military education institutions were often referred to education as the formation of professional military skills and knowledge through practical learning and training activities, while academic institutions perceived education based on theoretical and intellectual learning. Foot (2001) argues that after the WWII there was no distinct role for academic education in professional military education in Europe, thus officer education was mostly based on training. However, the Falklands War in 1982 clearly showed the limitations of such approach to officer education for that the military as professionals had to operate in a wider security agenda (Foot, 2001), which indicated the demand for academic education in the area of defence and security.

The need for academic knowledge within professional military education became rather obvious due to the intense changes of operational environment after the Cold War. Rapidly globalizing world and growing importance of international 
security required the military to operate in a complex multifaceted environment. It emphasized the need for diverse civilian and military skills, thus education and training started to be perceived as complementary and integral parts of professional military education (Libel, 2016), which further evolved into the concept of military higher education.

Fletcher (2009) makes a clear distinction between military training and education arguing that training provides professional skills required for the implementation of military tasks, whereas education provides the ability to decide how and when acquired professional skills may be applied. Paile (2010) also distinguishes academic and vocational aspects of contemporary military higher education in Europe, though, admitting that the EU countries have different approaches to organizing professional military education due to historical reasons. Contemporary military higher education in Europe is no longer limited to member states as the influence of the Bologna Process launched at the end of 1990s promotes the development of common higher education culture and fosters the Europeanization of education policies leading to standardization of officer education (Paile, 2010).

With the reference to the works of Fletcher (2009), Paile (2010), Foot (2001) and Libel (2016), it can be stated that professional military education is a complex phenomenon constituted of training and education, where training may be referred to as practical learning related to professional skills of 'management violence', while education may be referred to academic or intellectual learning related to the ability to decide how and when acquired professional skills may be applied in the changing operational environment.

Thus, in the context of professional military education, officer education may be defined as officer preparation to perform professional duties through intellectual learning and development of academic knowledge.

\section{Officer Education Models in Europe}

Professional military education as an institutionalized field of vocational education is quite widely discussed within the academic society. Scientists Masland, Radway (1957) and Foot (2001) researching the genesis of officer education note that the professionalization of officer education in Europe began in the 19th century and developed further after the WWII. A rather distinct analysis of officer education in Europe was proposed by Foot (2001). Analyzing the nature of activities of officer education institutions in Europe, referring to the balance between training and education and comprising officer preparation, Foot (2001) suggests the division of officer education into three distinct models, namely the 'Jena', the 'Falklands' and the 'Kosovo', which define the development of officer education paradigms.

According to Foot (2001), the 'Jena' model emerged after the Prussian defeat in the Battle of Jena in 1806 and, consequently, a major reform of officer education was introduced in order to prevent a similar defeat. The model ensured 
a rigorous systemic training of officers focusing on the professional competencies and qualifications, however, academic education played a small or no role in officer preparation.

The basic assumption behind this model is that state security is limited to country's political, economic and social context in which military personnel is operating. The focus on the national or internal dimension of operational activity within this model has limited the tasks of military personnel education system to exclusively professional officer training. The 'Jena' model, focusing on the preparation of military professionals, was highly valued in a stable strategic environment and after the WWII it was adopted in most European countries, such as France, Great Britain, Germany, Soviet Union, etc.

Nevertheless, the Falklands War in 1982 showed that the dimension of military operational activity is complex and the concept of security covers not only national but also international context, which is why it is important for officers as professionals to have academic knowledge related to national and global security. In the 'Falklands' model, a certain amount of officers who completed vocational military education were selected for further academic studies in order to prepare officers to operate in an international environment.

The 'Kosovo' model expanded the concept of the 'Falklands' model and was based on the assumption that the conditions under which armed forces operate are complex and multi-faceted. Thus, national interests may be far beyond the borders of the state, legal, political and social contexts may be quite controversial, tactical problems can rapidly and unpredictably transform into strategic issues and the supervision of military operations can be carried out at the highest political level (Foot, 2001). Continuous action under dynamic operational conditions in a changing security environment requires officers to be capable of conceptualization, political analysis and decision-making. Within the framework of the 'Kosovo' model, officers from the lowest to the highest rank should be able to assess the tactical, operational or strategic situation from different perspectives, make timely and proficient decisions, which then ought to be actualized by appropriate orders, directives or laws. In order to operate effectively in such an environment, professional military education should integrate professional military training on the one hand and academic studies on the other hand.

Further change of officer education paradigm may be associated with the so-called Europeanization process, which primarily reflects in the development of officer education models in Europe (Libel, 2016).

\section{The Evolution of the ESDI and Europeanization of Officer Education}

Libel (2016) argues that the development of the CSDP fosters the changing paradigms of officer education and contributes to the Europeanization of officer education. Therefore, the development of the European identity in security and 
defence may be referred to as one of the main factors of officer education policy development in Europe.

The development of the European identity in security and defence began with the establishment of the North Atlantic Treaty Organization (NATO) in 1949 (Bailes, 1999). New challenges and emerging threats contribute to the ongoing review and evaluation of the EU Security and Defence Policy. In the changing European security environment, ensuring a unified and coherent security and defence is one of the key priorities. However, after the WWII, the concept of the European security and defence was inseparable from the development of NATO. Richards (2001) defines the evolution of the European identity within two distinct contexts, i.e. through the ESDI development as a means of strengthening NATO and the ESDP development as a significant divergence of the European defence away from the Euro-Atlantic concept towards a more autonomous European approach.

The researches in this area provide a sufficiently clear view of the European identity development and dynamics. With the reference to the works of Bailes (1999), Richards (2001), Flechtner (2006), Anderson and Seitz (2006) and Blockmans (2016), the following three stages of the European identity development can be distinguished:

1. European Identity Stagnation - from the establishment of NATO to the end of the Cold War. At this stage, NATO was a dominant player in the European defence planning and development, so the European identity in security and defence was not clearly defined.

2. ESDI Formation. The concept of the European identity in the domain of security was proposed at the NATO Summit in London (NATO, 1990) in 1990. The ESDI was defined in 1996 in the Berlin Communique (NATO, 1996) and endorsed by the Atlantic Alliance Summits held in Madrid (NATO, 1997) and Washington (NATO, 1999). In accordance with these resolutions, NATO retains the responsibility for collective defence on the basis of 'separable but not separate' capabilities concept, which defines the way NATO capabilities could be used to defend Europe. However, according to these resolutions, European defence ambitions are limited to crisis management and EU is restrained from duplicating the structures of NATO forces.

3. ESDP/CSDP Formation. In 1999, the EU Council decided to allocate necessary resources to enable the development of the ESDP in order to provide the EU with autonomous defence structures. This signified the transition from the ESDI to the ESDP concept which involved the EU countries outside NATO, although the political mandate was limited to humanitarian, rescue and peacekeeping tasks in crisis management (Flechtner, 2006). According to Anderson and Seitz (2006), the ESDP lacked a clear political concept and its implementation could have weakened the transatlantic unity. The ESDP was renamed the Common Security and Defence Policy in the Lisbon Treaty (EU, 2007).

The European identity in security and defence acquired a qualitatively new 
dynamics after the Crimean annexation during the military conflict in Ukraine in 2014. As for the Brexit referendum, a deteriorating security context has led to the emergence of a new European defence discourse emphasizing the need for a stronger European defence.

According to Blockmans (2016), the concept of security has expanded in response to a changing security environment recognizing that security issues are multidimensional, incorporate internal as well as external threats and integrate defence concept. However, these changes also contributed to the change of the European identity: growing ambitions of the European defence go far beyond crisis management. Since 2016 and onwards, the initiatives to establish a permanent operational headquarters and European Defence Fund and standardize the requirements for the European defence industry have been gradually taking place (Blockmans, 2016).

Blockmans (2016) argues that in the changing European security environment the boundaries between internal and external security tend to become not so rigorous. In the context of international terrorism and crime, national security is inseparable from international security, and, therefore, the EU countries should realize that in the short term the restructuring of armed forces is inevitable in order to achieve sustainability and effectiveness of the European security and defence in a long term.

The growing link between national and international security promotes changes in officer education and training. In order to be able to deploy within multinational contingent, the armed forces of the EU member states must share similar standards. This trend consequently leads to the adoption of a common officer education model and gradual Europeanization of officer education. Libel (2016) describes Europeanization as a process of integrating common European rules and practices at the national level. Therefore, in order to form a homogenous military compound consisting of the EU member states' armed forces, the standardization of military personnel education and training is carried out at the operational level which altogether forms the basis for the Europeanization process of military personnel.

On the basis of the CSDP development, Libel (2016) defines a new officer education paradigm delineated within the concept of National Defence University. Based on this concept, Libel (2016) states that changes in officer training and education are driven by changing security environment, and, therefore, the ability of officers as professionals to conduct operations is valued more than the ability to actually fight on the battlefield. This evolving paradigm of military education manifests itself in the concept of National Defence University and contributes to the development of officer Europeanization process as officers from different EU countries acquire common military ethics and culture standards while attending multinational courses at national defence universities. Libel (2016) states that when critical masses of such officers will be achieved in the EU countries, a shift in national strategic culture paradigms will take place thus creating preconditions for 
a common EU military culture.

The dynamics of contemporary security environment prompts the EU to pay special attention to the formation of officer education policy. On the basis of the EU Military Training and Education Annual Report 2016 issued by the EU Military Committee (EUMC, 2017), it can be argued that in 2012 the EU has begun the development of a coherent policy for officer training and education in order to optimize the use of available resources within the CSDP. The EU Military Training Group was set up to unify military training requirements. It launched military training on common disciplines, took steps towards strengthening the dialogue with NATO military personnel training and created an online crisis portal management training. The group organizes conferences and meetings on a regular basis to address current issues of military personnel training and education.

In the context of the consistent development of the CSDP, a great deal of attention is paid to the standardization of officer training and education in the EU, hence a new training policy is under development to be approved by the EU Council. In a long term, the CSDP aims to unify the EU military training and education system, establish a joint military training plan for all the EU countries and improve the quality of officer training and education in order to ensure the compliance with international standards and requirements (EUMC, 2017).

To sum up, it can be stated that after the WWII, the development of the ESDI and CSDP have contributed to the Europeanization process of officer education, which is reflected in the concept of National Defence University.

\section{The Development of Officer Education Policy}

Officer education policy is a multidimensional and complex phenomenon; therefore, in order to distinguish the development cycle, it is crucial to examine the existing models and to identify the main elements of officer education policy formation.

One of the most exhaustive descriptions of officer education models was proposed by Foot (2001), who distinguished three models of officer education - the 'Jena', the 'Falklands' and the 'Kosovo'. The analysis of the 'Jena' model showed that the presuppositions for this model development can be associated with the defeat of Prussia by superior French troops in the Battle of Jena in the beginning of the 19th century. The defeat demonstrated that the Prussian army was not able to respond effectively to the emerging threats in the changing security environment. After the defeat, Prussia's defence and security policy began to change in order to prevent a similar defeat (Foot, 2001), and, therefore, the concept of a regular professional army was replaced by the concept of universal (compulsory) military service, which allowed the mobilization of a sufficiently large number of trained soldiers within a short period of time (Posen, 1993). As a result of this policy, the Prussian military performed the functions of deterrence and rapid response to enemy 
aggression. Also, new requirements, such as prompt mobilization, professionalism of officers and high state of readiness (Posen, 1993) were introduced to the armed forces. Officer education reform was carried out to create a functional army under the changed security conditions. Consequently, it led to the emergence of a new officer education model.

On the basis of theoretical analysis of the 'Jena' model, the following four main factors leading to the emergence of this model can be distinguished:

\section{The 'Jena' model}

1. Emerging threats: the imperialist ambitions of France.

2. Changing security environment: the military conflict between France and Prussia.

3. Changing security and defence policy: from regular professional army to universal military service.

4. Changing requirements for the armed forces: prompt mobilization, professionalism of officers and high level of readiness.

Further analysis of the 'Falklands' and 'Kosovo' models shows that the shift in officer education models is caused by similar factors.

\section{The 'Falklands' model}

1. Emerging threats: challenges to the interests of the Western countries in the global environment.

2. Changing security environment: military conflict in the Falkland Islands and the Iran-Iraq War.

3. Changing security and defence policy: national security concept is inseparable from the concept of global security.

4. Changing requirements for the armed forces: the military must be able to act outside the national context, i.e. in the global environment; officers must have the knowledge of global security.

\section{The 'Kosovo' model}

1. Emerging threats: challenges to national interests outside the state.

2. Changing security environment: military conflict in Kosovo.

3. Changing security and defence policy: the concept of state security covers not only national but also international context.

4. Changing requirements for the armed forces: the military must be able to carry out peacekeeping operations in a contradictory legal, political and social context; officers must have conceptualization, political analysis and decisionmaking competencies. 
In his study of professional military education, Libel (2016) acknowledges that changes in officer training and education are driven by newly emerging threats and a changing security paradigm. In addition to Foot (2001), Libel (2016) defines a new officer education model based on the concept of National Defence University. According to Libel (2016), the emergence of national defence universities as a new officer preparation model was the result of military recession in Europe after the end of the Cold War and the disappearance of direct threats. The concept of a widespread military conflict was replaced by crisis management operations in European countries. In the context of the recession, the CSDP has become a tool for crisis management, and the Europeanization of national defence was perceived as a natural way to make effective use of reduced resources. The process of Europeanization has imposed new requirements on the armed forces: the military must be able to carry out complex joint operations within the international contingent in order to respond to emerging threats, such as ethnic wars, international terrorism and crime (Libel, 2016). With reference to Libel (2016), officer education models defined by Foot can be supplemented with the following fourth model:

\section{The 'National Defence University' model}

1. Emerging threats: international terrorism, ethnic wars and military recession.

2. Changing security environment: terrorist attacks in the EU countries and declining funding for defence and security.

3. Changing security and defence policy: the Europeanization of national defence and security in order to compensate the reduced funding of the armed forces.

4. Changing requirements for the armed forces: the military must be able to carry out complex joint operations within the international contingent.

Further analysis of factors contributing to the development of officer education models indicates the reactive dynamics of change in officer education policy. The change performs the function of adaptation to the changing security environment in order to ensure the armed forces' capacity to respond adequately to newly emerging threats. Therefore, the institutionalization of the officer education model is associated with changes at the strategic level. The legitimization of new operational requirements for the armed forces within unstable security environment is carried out at the strategic-political level and is reflected in doctrines, directives, laws and other strategic documents. Officer education policy is formulated on the basis of these documents. Consequently, based on the analysis of the factors influencing the development of officer education models, it is possible to theoretically define the cycle and stages of officer education policy development (see Figure 1). 


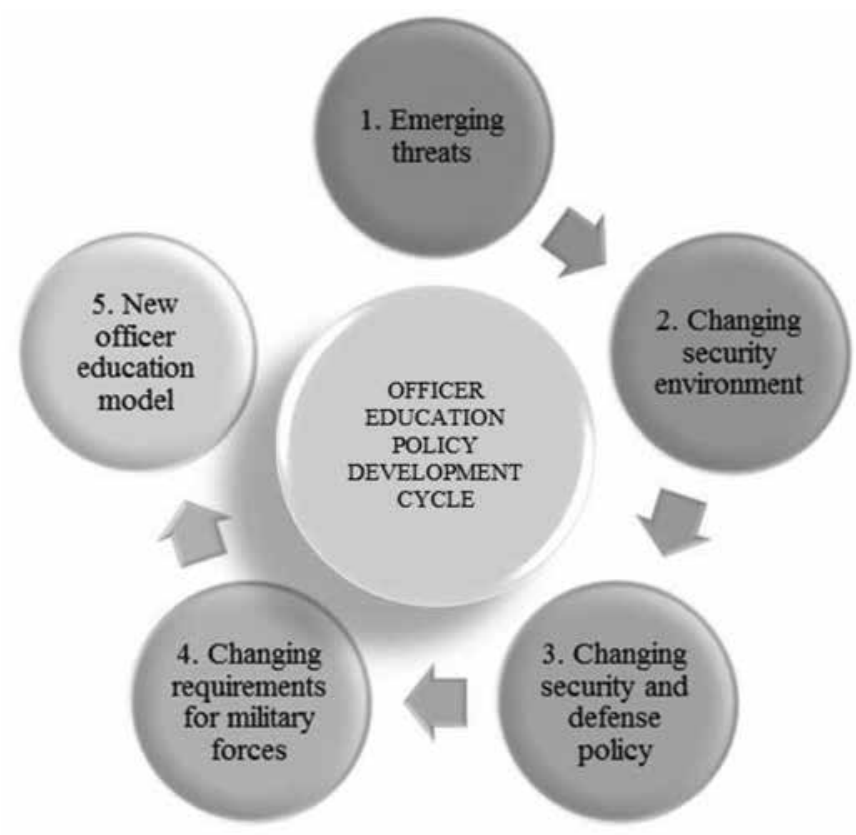

Figure 1. Officer education policy development model (prepared by the author)

Thus, it can be stated that officer education policy development is a cyclic phenomenon consisting of five main elements (see Figure 1). The prerequisite for the cycle change is the emergence of new threats in response to which the security and defence policy is changing and new requirements are imposed on the armed forces. In order to meet the new requirements, a new model of officer education is developed as the basis of functional armed forces.

The emergence of the latest officer education model defined by Libel (2016) was stimulated by the European military recession which was reflected in reduced funding for defence and security. However, after the military conflict in Ukraine and Syria, a rapid change of security environment has taken place. As a response to new security threats, many European countries have revised their defence and security policies. In regard to the officer education policy development model, it can be stated that it is a continuous process and current trends encourage further evolution of officer education policy.

\section{Conclusions}

1. Professional military education is a complex phenomenon which includes training as practical learning related to professional skills and education as intellectual learning related to the ability to decide how and when acquired professional skills may be applied within a complex operational environment. Therefore, officer education may be defined as the preparation of officers to perform professional 
duties through intellectual learning and development of academic knowledge.

2. The interchange of officer education models is closely linked to the security environment, while the change of officer education paradigms in Europe is fostered by the armed forces' inability to respond effectively to the emerging threats and perform military tasks in a changed strategic, tactical or operational environment. The interchange of officer education paradigms has led to the emergence of the following four distinct models of officer education: the 'Jena', the 'Falklands', the 'Kosovo' and the 'National Defence University'. The emergence of the latest officer education model defined by Libel (2016) may be associated with the development of the CSDP. The formation of a homogenous military compound consisting of joint armed forces from the EU member states requires the standardization of military personnel education and training at operational level, which forms the basis for the Europeanization process of military personnel.

3. The development of officer education policy is a cyclic process. The following four main factors determining the change of officer education model may be distinguished: emerging threats, changing security environment, changing security and defence policy and changing requirements for the armed forces. In order to fulfil the new requirements for the military, a new officer education model is formed. The emergence of the new model leads to a consequent cyclic development of officer education policy. On the basis of the contextual analysis of four officer education models in Europe, it can be stated that theoretical officer education policy development model contains five main elements: emerging threats, changing security environment, changing security and defence policy, changing requirements for the armed forces and new officer education model.

\section{References}

1. Anderson, S., Seitz, T. R. 2006. European Security and Defence Policy Demystified. Nation-Building and Identity in the European Union. Armed Forces \& Society, Volume 33, Number 1, October 2006, p. 24-42.

2. Bailes, A. J. K. 1999. NATO's European Pillar: The European Security and Defence Identity. Defence Analysis Vol. 15, No. 3, p. 305-322.

3. Black, J., Hall, A., Cox, K., Kepe, M. And Silfversten, E. 2017. Defence and Security after Brexit. Understanding the Possible Implications of the UK's Decision to Leave the EU. Overview report. RAND Corporation, Santa Monica, Calif., and Cambridge, UK.

4. Blockmans, S. 2016. The 2016 'Winter Package” on European Security and Defence: Constitutional, Legal and Institutional Implications. In-depth analysis. Directorate General for Internal Policies Policy Department C: Citizens' Rights and Constitutional Affairs Constitutional Affairs, European Union.

5. Downes, C. J. 1985. To Be or Not to Be a Profession: The Military Case. Defence Analysis, 1(3), p. 147-171. 
6. European Union Military Committee. 2017. EU Military Training and Education Annual Report 2016. Council of the European Union, Brussels. Accessed on 01.08.2018. http://data.consilium.europa.eu/doc/document/ST-8601-2017-INIT/ en/pdf

7. European Union. 2007. Treaty of Lisbon Amending the Treaty on European Union and the Treaty Establishing the European Community (2007/C 306/01). Accessed on 01.08.2018 https://eur-lex.europa.eu/legal-content/EN/ TXT/?uri=celex:12007L/TXT

8. Flechtner, S. 2006. European Security and Defence Policy: Between 'Offensive Defence' and 'Human Security'. Internationale Politikanalyse, International Policy Analysis Unit, Friedrich-Ebert-Stiftung, p. 157-173.

9. Fletcher, J. D. 2009. Education and Training Technology in the Military. Science, 323(5910), p. 72-75.

10. Foot, P. 2001. European Military Education Today. Baltic Defence Review, Volume No. 5 2001, p. 12-31.

11. Huntington, S. P. 1981. The Soldier and the State: The Theory and Politics of Civil-Military Relations. Harvard University Press.

12. Leadership and Education. Defence Command Denmark, Forlaget Vandkunsten, Copenhagen, 2008.

13. Libel, T. 2016. European Military Culture and Security Governance. Routledge, Taylor and Francis Group, London and New York.

14. Masland, J. W, Radway, L. I. 1957. Soldiers and Scholars. Military Education and National Policy. London: Oxford University Press.

15. North Atlantic Treaty Organization. 1990. North Atlantic Council London 5-6 July 1990. London Declaration On A Transformed North Atlantic Alliance, Issued by the Heads of State and Government participating in the meeting of the North Atlantic Council, North Atlantic Council, London, 5-6 July 1990. Accessed on 01.08.2018 https://www.nato.int/docu/comm/49-95/c900706a.htm

16. North Atlantic Treaty Organization. 1996. Press Communique M-NAC-1(96)63, Ministerial Meeting of the North Atlantic Council, Berlin 3 June, 1996, Final Communique. Accessed on 01.08.2018 https://www.nato.int/docu/ pr/1996/p96-063e.htm

17. North Atlantic Treaty Organization. 1997. Press Release M-1 (97)81, Meeting of the North Atlantic Council, Madrid, 8 July 1997. Madrid Declaration on Euro-Atlantic Security and Cooperation. Issued by the Heads of State and Government. Accessed on 01.08.2018 https://www.nato.int/docu/pr/1997/p97-081e.htm

18. North Atlantic Treaty Organization. 1999. Press Release NAC-S(99)64 24 Apr. 1999. Washington Summit Communique. Issued by the Heads of State and Government participating in the meeting of the North Atlantic Council in Washington, D.C. on 24 April 1999. Accessed on 01.08.2018 https://www.nato.int/ docu/pr/1999/p99-064e.htm

19. Paile, S. 2010. The European Military Higher Education Stocktaking 
Report. Council of the European Union DG F, Brussels.

20. Posen, B., R. 1993. Nationalism, the Mass Army and Military Power. International Security, Vol. 18, No. 2, p. 80-124.

21. Richards, L. C. C. 2001. The Evolution of a European Security Identity: Implications for Canada. Exercise New Horizons, Canadian Forces College, CSC 27 , p. $145-157$. 


\title{
KARININKŲ ŠVIETIMO POLITIKOS PLE்TRA KINTANČIO ES SAUGUMO IR GYNYBOS IDENTITETO KONTEKSTE
}

\author{
Kpt. Aleksandras Melnikovas \\ Generolo Jono Žemaičio Lietuvos karo akademija
}

\section{Santrauka}

Saugumo aplinkos destabilizavimas, technologinè plètra ir konceptualūs karinių konfliktų pokyčiai prisideda prie nuolatinio karinio personalo rengimo ir švietimo politikos vystymosi. Siekiant užtikrinti karinių pajègų funkcionalumą besikeičiančioje aplinkoje, ypatingas dėmesys yra skiriamas karininkų rengimui. Karininkų rengimas ir švietimas yra labai svarbi karinių pajègų parengties ir profesionalumo užtikrinimo priemonè, kuri tiesiogiai prisideda prie nacionalinio ir tarptautinio saugumo.

Karininkų rengimas yra kompleksinis reiškinys, kurị sudaro profesinis karinis rengimas, skirtas ugdyti profesinius igūdžius, ir švietimas, skirtas suteikti akademinių žinių. Profesinis karinis rengimas yra susijęs su praktiniu mokymu arba ,smurto vadyba“, tuo tarpu švietimas padeda ugdyti gebejjimą nuspręsti, kaip ir kada ịgytas profesines žinias galima taikyti kintančioje aplinkoje. Karininkų rengimo paradigmų kaita gali būti apibrèžta analizuojant karinių švietimo ịstaigų veiklą Europoje ir atsižvelgiant ị pusiausvyrą tarp profesinio karinio rengimo ir švietimo. Remdamasis karinių švietimo ịstaigų veiklos analize Foot (2001) išskiria tris karininkų rengimo modelius: „Jenos“, „Folklandų“ ir „Kosovo“. Tolesnè karinio rengimo paradigmy kaita gali būti siejama su Europeizacijos procesu, kuris prisidèjo prie naujo karininkų švietimo modelio - nacionalinio gynybos universiteto - atsiradimo.

Karininkų švietimo modelių kaitos veiksnių analizė rodo, jog karininkų švietimo politika yra dažniausiai reaktyvaus pobūdžio: karininko švietimo modelio kaita atlieka prisitaikymo prie besikeičiančios saugumo aplinkos funkciją, siekiant užtikrinti karinių pajègu gebejjimą tinkamai reaguoti ị kylančias grèsmes. Todėl karininkų švietimo modelių institucionalizavimas siejamas su strateginio lygmens pokyčiais - naujų operacinių reikalavimų karinėms pajègoms ịteisinimas nestabilioje saugumo aplinkoje vykdomas strateginiu-politiniu lygmeniu ir atsispindi doktrinose, direktyvose, ịstatymuose ir kituose dokumentuose. Remiantis šiais dokumentais, formuojama karininkų švietimo politika.

Tolesnè keturių karininkų švietimo modelių analizè atskleidè, kad karininkų švietimo politikos plètra yra ciklinis procesas, todèl gali būti išskirti keturi pagrindiniai karininko švietimo politikos formavimo veiksniai: kylančios grèsmès, besikeičianti saugumo aplinka, kintanti saugumo ir gynybos politika, kintantys reikalavimai karinėms pajègoms. Siekiant įvykdyti naujus reikalavimus karinėms pajëgoms, laipsniškai formuojamas naujas karininkų švietimo modelis, kuris užbaigia karininkų švietimo politikos vystymosi ciklą. 


\section{AUTORIAUS LYDRAŠTIS}

Autoriaus vardas, pavardè: Aleksandras Melnikovas

Mokslo laipsnis ir vardas: edukologijos magistras

Darbo vieta ir pareigos: Generolo Jono Žemaičio Lietuvos karo akademija, doktorantas

Autoriaus mokslinių interesų sritys: Lietuvos saugumo ir gynybos politika, profesinis karinis rengimas ir švietimas, karininkų rengimo ir švietimo politika, Europos Sajungos bendro saugumo ir gynybos politika, Europos saugumo ir gynybos identitetas, Europeizacija.

Telefonas ir el. pašto adresas: +370622567 99;

aleksandras.melnikovas@mil.lt, a.melnikovas@gmail.com

\section{AUTHOR'S COVER LETTER}

Author's name and surname: Aleksandras Melnikovas

Academic degree and name: Master of Education

Workplace and position: doctoral student, General Jonas Žemaitis Military Academy of Lithuania

Author's research interests: Lithuanian Security and Defence Policy, professional military education and training, officer training and education policy, European Union Common Security and Defence Policy, European Security and Defence Identity, Europeanization

Telephone and e-mail address: +37062256799 ;

aleksandras.melnikovas@mil.lt, a.melnikovas@gmail.com 